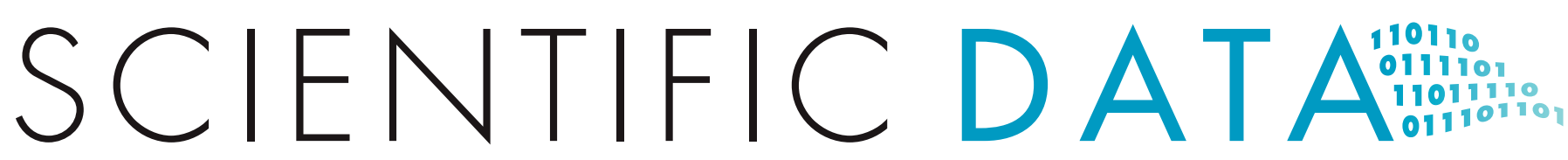

Published: 9 October 2018

\title{
Corrigendum: Transcriptomic analyses of murine ventricular cardiomyocytes
}

\author{
Morgan Chevalier, Sarah H. Vermij, Kurt Wyler, Ludovic Gillet, Irene Keller \& Hugues Abriel
}

Correction to: Scientific Data https://doi.org/10.1038/sdata.2018.170, published online 21 August 2018.

In the CASK and SAP97 knockout mice sub-section of the Methods in this Data Descriptor it is incorrectly stated that CASK KO mice were generated as previously published in references 9 and 20. This is incorrect. Instead, mice in which the first coding exon of the CASK gene is flanked by loxP sites (CASK $^{\mathrm{tm} 1 \mathrm{Sud}}$, purchased from the Jackson Laboratory, stock \#006382) were crossed with $\alpha \mathrm{MHC}$ Cre mice.

In the same section of the Data Descriptor it is incorrectly stated that in SAP97 mice the first SAP97 gene was floxed. In actuality the first three coding exons were floxed.

In Table 4 of the Data Descriptor, the genotype of samples SAP_Ct1, SAP_Ct2 and SAP_Ct3 is incorrectly listed as WT+Cre. The correct genotype is WT_fl, consistent with Figure 2 and the Mouse models sub-section of the Methods.

(c) (i) Open Access This article is licensed under a Creative Commons Attribution 4.0 International License, which permits use, sharing, adaptation, distribution and reproduction in any medium or format, as long as you give appropriate credit to the original author(s) and the source, provide a link to the Creative Commons license, and indicate if changes were made. The images or other third party material in this article are included in the article's Creative Commons license, unless indicated otherwise in a credit line to the material. If material is not included in the article's Creative Commons license and your intended use is not permitted by statutory regulation or exceeds the permitted use, you will need to obtain permission directly from the copyright holder. To view a copy of this license, visit http://creativecommons. org/licenses/by/4.0/

(C) The Author(s) 2018 